\title{
Recovery of basic valuable metals and alloys from E-waste using microwave heating followed by leaching and cementation process
}

\author{
RAJENDRA PRASAD MAHAPATRA ${ }^{1,2, *}$, SATYA SAI SRIKANT ${ }^{2}$, \\ RAGHUPATRUNI BHIMA RAO ${ }^{3}$ and BIJAYANANDA MOHANTY ${ }^{1}$ \\ ${ }^{1}$ National Institute of Technology Mizoram, Aizawl 796012, India \\ ${ }^{2}$ SRM Institute of Science and Technology, Modinagar 201204, India \\ ${ }^{3}$ CSIR-Institute of Minerals and Materials Technology, Bhubaneswar 751013 , India \\ e-mail: rp.mahapatra2018@gmail.com; satyas@srmist.edu.in; satya.srikant@gmail.com; \\ dr.r.bhimarao@gmail.com; bijayananda.mohanty@gmail.com
}

MS received 16 December 2018; revised 3 August 2019; accepted 6 August 2019

\begin{abstract}
The whole world understands about the crisis of harmful electronic waste as it is increasing the usage and its disposal. The Government of India asked researchers to come out with innovative alternative solutions, apart from existing conventional methods for safe reuse, recycling and proper disposal particularly for electronic solid waste system. The solution is found which consists of microwave heat treatment followed by acid leaching. The e-waste was first crushed and then the sample was melted in microwave heat treatment to recover the valuable metal in the form of metallic mixture. This mixture was further subjected to acid leaching process in the presence of hydrogen peroxide to form leached liquor. The analysis with X-ray diffraction, image mapping and energy-dispersive X-ray spectroscopy shows that the leached liquor sample mainly contain iron, aluminum and copper, mostly in the form of alloys. The results with field-emission scanning electron microscope analysis, also shows that approximately ninety percent leaching efficiency is observed for nickel, cobalt and copper with hydrochloric acid as solvent, whereas iron and aluminum produced less than forty percent. Further, these results are also compared with the existing methods based on the response surface method through thermal plasma process.
\end{abstract}

Keywords. E-waste; printed circuit board; microwave heating; leaching; cementation.

\section{Introduction}

In the 21 st century, the usage as well as the utilization and production of electronic materials both for business and household purposes have expanded exponentially step by step and have compounded the problem of piling electronic waste (e-waste). Low prices, new technologies innovation and addition of new features are also causing the replacement of electronic products at a quicker rate [1]. In both developed and developing countries, it creates a huge quantity of wastes in the form of obsolete electrical and electronic products [2]. E-waste is chemically and physically different from other forms of municipal or industrial waste; it contains both valuable and harmful materials that require special handling and recycling processes to avoid environmental pollution/contamination and hazardous effects on human health [3-8].

Recycling and disposal of huge amount of e-waste, generated in India, is mostly done by ordinary methods, which causes environmental and health hazards $[3,9,10]$. Presently,

*For correspondence

Published online: 11 September 2019 e-waste processing is performed in three major steps, namely disassembling (taking out hazardous or valuable components), upgrading (mechanical or metallurgical technique to recover desirable materials content) and refining (purification process of recovered materials). Moreover, mechanical processing separates the metallic part out of the e-waste, leaving aside a huge amount of plastic and harmful components. It causes huge amount of waste. Thus, total disposal of the e-waste is not possible through mechanical routes [10-13]. Environmental pollution is caused by the treatment or handling of poor and improper recycling processes by release of toxic materials in e-waste from landfilling or treatment or from the end-products and compounds after these procedures $[1,4,14]$. Due to the presence of halogenated flame retardants (HFR) in the feed of e-waste, it causes formation of dioxins, which are very harmful. Due to this reason, conventional hydrometallurgical processes have been preferred in order to recover individual metals from e-waste. This process includes various types of leaching like cyanide leaching, thiosulfate leaching, halide leaching, etc. and processes include de-polarizing technique, filtering, 
solvent extraction, cementation, demagnetization and ion exchange $[15,16]$. Abdul Khaliq and his team highlighted the limitation of using hydrometallurgical processes to recover the precious metal from e-wastes as such process are slow and time consuming, which are very much related to economy of hydrometallurgical routes compared to pyrometallurgical processes [15]. They also highlighted about the serious health risks to the inhabitants on using the dangerous leachant like cyanide, halide leaching, thiourea-based gold leaching, thiosulfate leachant, etc. on hydrometallurgical routes to recover the precious metals from e-wastes. So, they suggested pyrometallurgical processes which are economical and eco-efficient for the recovery of precious metals from e-wastes, but however hazardous flue emissions need to be minimized from environmental pollution. Liu and his team recovered the copper with waste printed circuit boards with electrolysis process but more researches are required for industrial application [17]. In recent times, scan of literature reveals that researchers achieved a success on e-waste with the applications of bio-leaching. But it is very important that one need to understand the metal impacts and other organic and inorganic impurities on the extraction rate and total recovery of the target metals by bioleaching [18-22]. However, it can be noted that bioleaching is a time taking process. The main demerit of such controlled indirect leaching (bioleaching) process is that it has to support microbial growth and time medium may have to be made to enable controlling of other secondary reaction [18]. Due to these reasons, it is decided in the present investigation to carry out the some other resources for e-waste.

Microwave energy provides the great advantage for heating to dispose of waste, such as selective heating, rapid heating, the ability to heat the waste, reduction in waste volume, enhanced chemical reactivity, high temperature capabilities, eco-friendly process that can be controlled remotely and also be easily interfaced/integrated with other peripheral devices like computers, GSM/GIS/GPRS either by wired or wirelessly. It is easy to control, energy savings, overall cost effectiveness/saving technique, cleaner energy source and mainly user friendly process as compared to some more conventional systems, etc.

Microwave heating provides various kinds of real-world wastes more significantly as it provides a volumetric heating process (i.e., transfer of heat uniformly) at improved heating efficiencies as compared with conventional techniques [23-27]. A significant number of literatures have been reviewed in order to demonstrate the limitations of conventional methods and suggesting where microwave technology can offer both technical and financial benefits. The application of microwaves to materials is shown to be more successful in some processes than others. The potential for microwave heating to be applied to a process is dependent on the dielectric properties of the target material. Such properties are not fully understood. Not all materials possess the ability to absorb microwave radiation, which, although a limiting factor in some applications, can be advantageous in others. The wastes like printed circuit board material is assumed to be a low loss factor i.e., poor receptor to microwave energy means that granulated activated carbon or graphitic carbon (reducing agent) are very much required to facilitate heating and decomposition, as they are good receptor of microwave energy which plays a vital role of heating accelerator [25, 28].

Very few researchers have attempted with microwave energy to recover the useful and valuable metals from the e-waste. Therefore, keeping in view the hitherto known prior art, CSIR-Institute of Minerals and Materials Technology, India has attempted the research work of e-waste with microwave technology first time in order to provide a single step process for recovering the metal values from e-waste. This paper represents the novel approach of microwave heating method to recycle and reuse of the waste Printed Circuit Boards (PCBs). This novel method is not only used to recover a wide range of materials with ecofriendly process but also to produce various metallic and non-metallic phases. The e-waste material was first crushed/ground before feeding to the microwave furnace. This developed process eliminates the need for the mechanical disassembling step $[29,30]$. Due to temperature as high as $1450-1650^{\circ} \mathrm{C}$ inside the furnace, the harmful gases including dioxin gets decomposed and hence the flue gas generated consists allowable concentration of hydrocarbon, $\mathrm{CO}, \mathrm{NO}_{\mathrm{x}}, \mathrm{SO}_{2}$, dioxins, etc. This makes the process environment friendly. Useful metals were obtained in an alloy form and less amount of waste in the form of ash was generated. Copper has been recovered through acid leaching route in the present investigation. Further studies for residue are in process for more precious valuable metals like gold and silver.

\section{Materials and methods}

\subsection{Materials}

Waste samples of printed circuit boards, obtained from store room of Department of Computer Science Engineering, SRM University, Modinagar Campus, India. The electronic materials like electrolyte capacitors, batteries, small transformers and plastics from e-waste samples were removed first. However, some metal wires and epoxy base plates are very difficult to remove, so, they were separated or removed with some sharp instruments like cutter. The remaining PCB samples including Integrated Chips (ICs), after dismantling/removal by cutter, served as the raw material for our investigation.

\subsection{Microwave treatment of e-waste}

The raw materials were first shredded mechanically, into fragments of about $10 \mathrm{~mm} \times 10 \mathrm{~mm}$ and these fragmented samples were finally crushed into a fine particle state of 
approximately $250-300 \mu \mathrm{m}$ (i.e., 50-60 mesh) by dual planetary mills at CSIR-IMMT laboratory. Around $5 \mathrm{~kg}$ of crushed PCBs (e-waste materials) mixed with $200 \mathrm{~g}$ of silicon carbide powder (with 400 mesh size), which was kept in a quartz container, kept inside the microwave sintering furnace for heat treatment. The industrial microwave sintering furnace (available at CSIR-IMMT laboratory) having model G N Technologies, $2.45 \mathrm{GHz}$, output $6 \mathrm{~kW}$ with steps $5 \mathrm{~W}$ was used for microwave heating. The purpose of mixing the silicon carbide powder in the crushed PCB is to behave as a reducing agent and plays the role of a microwave heating accelerator. Due to low loss factor of some metal oxides present in crushed samples, the samples are poor receptor to microwave energy and then adding the carbon component provides the good receptor of microwave energy $[25,28]$. So, there is an extra arrangement of bed of graphitic carbon sample inside the quartz container containing the mixture of crushed samples and $\mathrm{SiC}$ powder. It further acts as the microwave-absorbent i.e., reducing agents. The arrangement of microwave heat treatment is shown in figure 1 .

The sample with the power of $3 \mathrm{KW}$ (i.e., $1.5 \mathrm{KW}$ both vertically as well as horizontally) produces the temperature of around $1100^{\circ} \mathrm{C}$. The presence of silicon carbide (SiC) susceptor further enhanced the heating process rapidly directly or indirectly $[25,27,28]$ and due to this, the temperature reaches in the range of $1450-1600^{\circ} \mathrm{C}$. A powder of small quantity of silicon carbide ( $\mathrm{SiC}$ ) acting as an additional reductant was spread near to e-waste sample when placed inside the microwave sintering furnace. An adequate argon gas (inert gas) pressure as shown in figure 1 was maintained for microwave sintering furnace to avoid any type of oxidation reaction $[27,28]$. The e-waste sample in microwave furnace was kept for 45 minutes for microwave heating.The product was obtained as a mixture of metal and non-metal (more of ash), out of which metallic part could be separated easily.

All the analysis of micro structural characterizations/morphologies of the metallic portion obtained after microwave treatment were performed with Field Emission Scanning Electron Microscope (FESEM) studies. This microscope with model Supra Zeiss 55 used for the present investigation with the resolution of $1 \mathrm{~nm} / 30 \mathrm{KV}$, which is interfaced with Oxford's Energy dispersive X-ray spectroscopy (EDX) detector [28]. It is used in the present investigation for image mapping of conducting and nonconducting samples without gold coating. The careful investigations with Field Emission Scanning Electron Microscope (FESEM) - Energy Dispersive X-ray Spectroscopy (EDX) analysis were carried out with HitachiS$3300 \mathrm{~N}$ (TEM/STEM/SEM). It has high precise resolution of $0.1 \mathrm{~nm} / 300 \mathrm{KV}$ and magnification varied from $200-500 \times$ to $2000-1500000 \times$, with AC voltage,varying from $100 \mathrm{KV}$ to $300 \mathrm{KV}$. In a vacuum evaporator, the mounted grains coated with gold were mounted on a SEM brass stub, while the sample (obtained after leaching process) was rotated very slowly.

\subsection{Leaching of the metallic product obtained from microwave heating}

The sample obtained from microwave furnace was first cooled down and then it was used for acid leaching studies using Hydrochloric acid but in a batch scale. Amount of acid to solubilize the metal values was calculated based

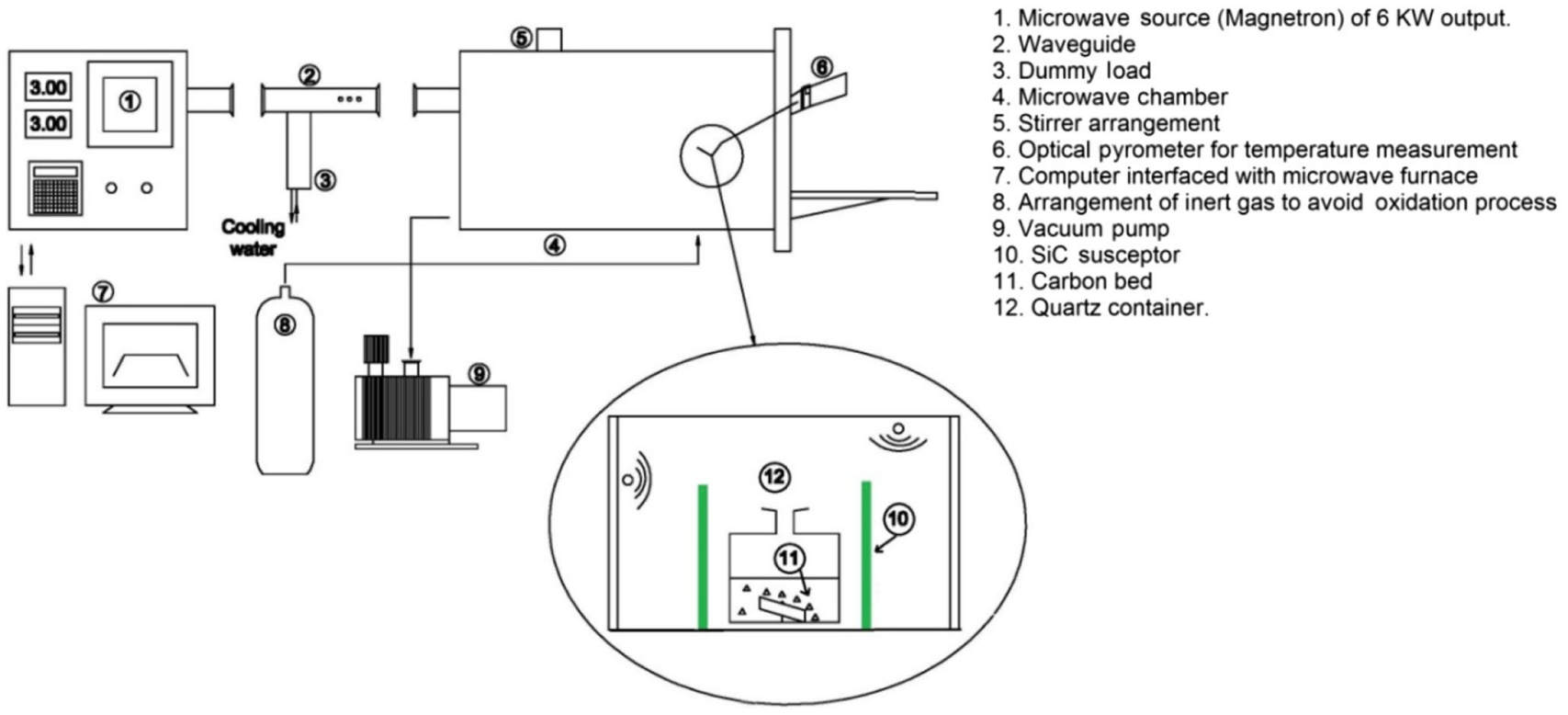

Figure 1. An arrangement of microwave heating of e-waste PCB. 
upon the stoichiometric requirement (e.g., $100 \mathrm{ml}$ of $16 \%$ acid solution of $35 \%$ grade $\mathrm{HCl}$ is required for $5 \mathrm{~g}$ of metallic powder of size less than $150 \mu \mathrm{m}$ ) of the metal values present in a typical size fraction. All leaching experiments were carried out using $100 \mathrm{ml}$ of lixiviant at room temperature. The mixing was done by a mechanical stirrer at speed of about $500 \mathrm{rpm}$. During leaching, $\mathrm{H}_{2} \mathrm{O}_{2}$ was introduced as depolarizer. Unless and otherwise stated, $5 \%$ pulp density, $5 \mathrm{ml} \mathrm{H}_{2} \mathrm{O}_{2}$ and $32 \%$ acid $(35 \%$ grade $\mathrm{HCl})$ were used for the leaching experiments of $5 \mathrm{~g}$ of e-waste powder of less than $150 \mu \mathrm{m}$ particle size in a lixiviant solution of $100 \mathrm{ml}$. All chemicals used were laboratory grade.

\subsection{Cementation}

The investigation of cementation process was carried out soon after acid leaching process. These investigations were carried out using leach liquor obtained from the leaching studies. Iron powder of commercial grade was used for precipitating $\mathrm{Cu}$, at a stoichiometric ratio of $1: 1$. The experiment was carried out at ambient temperature.

\subsection{Flowsheet}

All the above processes of entire investigations are represented in a single flowsheet shown in figure 2 with microwave processing.

\section{Results and discussions}

\subsection{Microwave treatment of e-waste}

Around $5 \mathrm{~kg}$ crushed e-waste samples were subjected to microwave treatment. It was observed that there was loss in weight of wastes during microwave treatment at different time periods. The loss in weight increased with the increase of time up to 20 minutes (i.e., from 60 minutes to eighty minutes). The total weight of heated samples after microwave heating remained with around $1800 \mathrm{~g}$ of metallic product and around $450 \mathrm{~g}$ of non-metallic product. The typical composition of the metallic product obtained with wet chemical analysis process, after microwave treatment are $54.3 \%$ copper $(\mathrm{Cu}), 12.99 \%$ of iron $(\mathrm{Fe}), 9.79 \%$ aluminium $(\mathrm{Al}), 0.28 \%$ lead $(\mathrm{Pb}), 1.13 \%$ nickel $(\mathrm{Ni}), 0.03 \%$ gold $(\mathrm{Au})$ and $0.07 \%$ silver $(\mathrm{Ag})$. The non-metallic portion which contained more of ash, which was removed easily by physical methods. In other words, the total loss was around $55 \%$ with $2750 \mathrm{~g}$ in weight. This loss is due to formation of typical flue gas in the form of carbon monoxide, sulphur dioxide, dioxins, furans and also due to loss of ignition (LOI). The content of typical flue gas compositions are $95 \mathrm{mg} / \mathrm{m}^{3}$ of carbon monoxide (CO), $245 \mathrm{mg} / \mathrm{m}^{3}$ of $\mathrm{NO}_{\mathrm{x}}$, $190 \mathrm{mg} / \mathrm{m}^{3}$ of sulphur dioxide $\left(\mathrm{SO}_{2}\right)$, lesser than $0.15 \mathrm{ng}$ (I$\mathrm{TEQ} / \mathrm{m}^{3}$ ) dioxins and furans, $80 \mathrm{mg} / \mathrm{m}^{3}$ of acidic components including hydrochloric acid $(\mathrm{HCl})$. After passing this flue gas from the scrubber and bag filter, the contents of total flue gas composition after scrubbing and filtering process are $54.5 \mathrm{mg} / \mathrm{m}^{3}$ of $\mathrm{CO}, 245 \mathrm{mg} / \mathrm{m}^{3}$ of $\mathrm{NO}_{\mathrm{x}}, 20 \mathrm{mg} /$ $\mathrm{m}^{3}$ of sulphur dioxide $\left(\mathrm{SO}_{2}\right)$, lesser than $0.15 \mathrm{ng}$ (I-TEQ/ $\mathrm{m}^{3}$ ) dioxins and furans, $6 \mathrm{mg} / \mathrm{m}^{3}$ of acidic components including hydrochloric acid $(\mathrm{HCl})$. Around $1225 \mathrm{~g}$ of metallic product was also obtained after scrubbing and filtering process.

During the flue gas studies, it is observed that there is an interaction between $\mathrm{HCl}$ and $\mathrm{SO}_{\mathrm{x}}$. It is seen that the $\mathrm{HCl}$ promotes the conversion of $\mathrm{SO}_{2}$ to $\mathrm{SO}_{3}$. The rate of conversion of $\mathrm{SO}_{2}$ to $\mathrm{SO}_{3}$ is included additionaly either at a high concentration of $\mathrm{HCl}$ with a high temperature, or at a low concentration of $\mathrm{HCl}$ with a low temperature [31]. It is also observed that there is formation of molecular chlorine $\left(\mathrm{Cl}_{2}\right)$, which causes the reduction of $\mathrm{HCl}$ emissions in flue

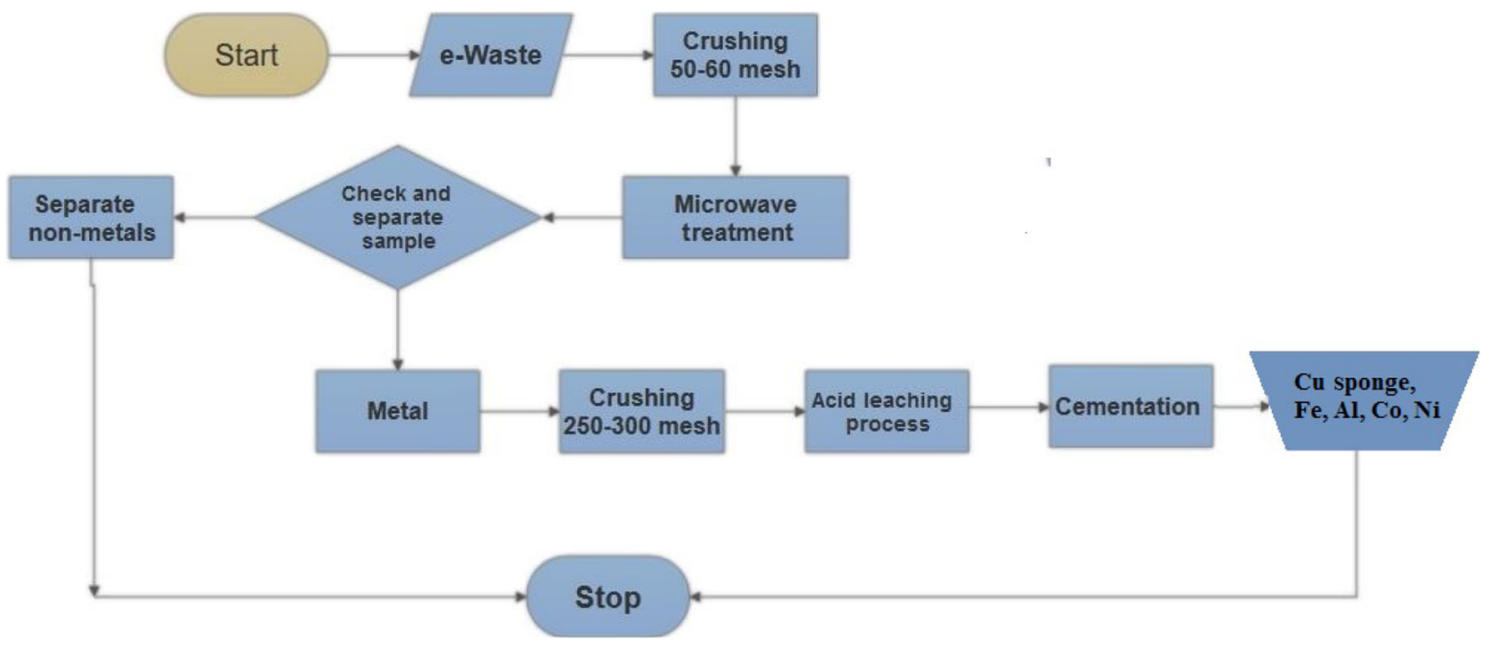

Figure 2. Flowsheet of the effective process. 

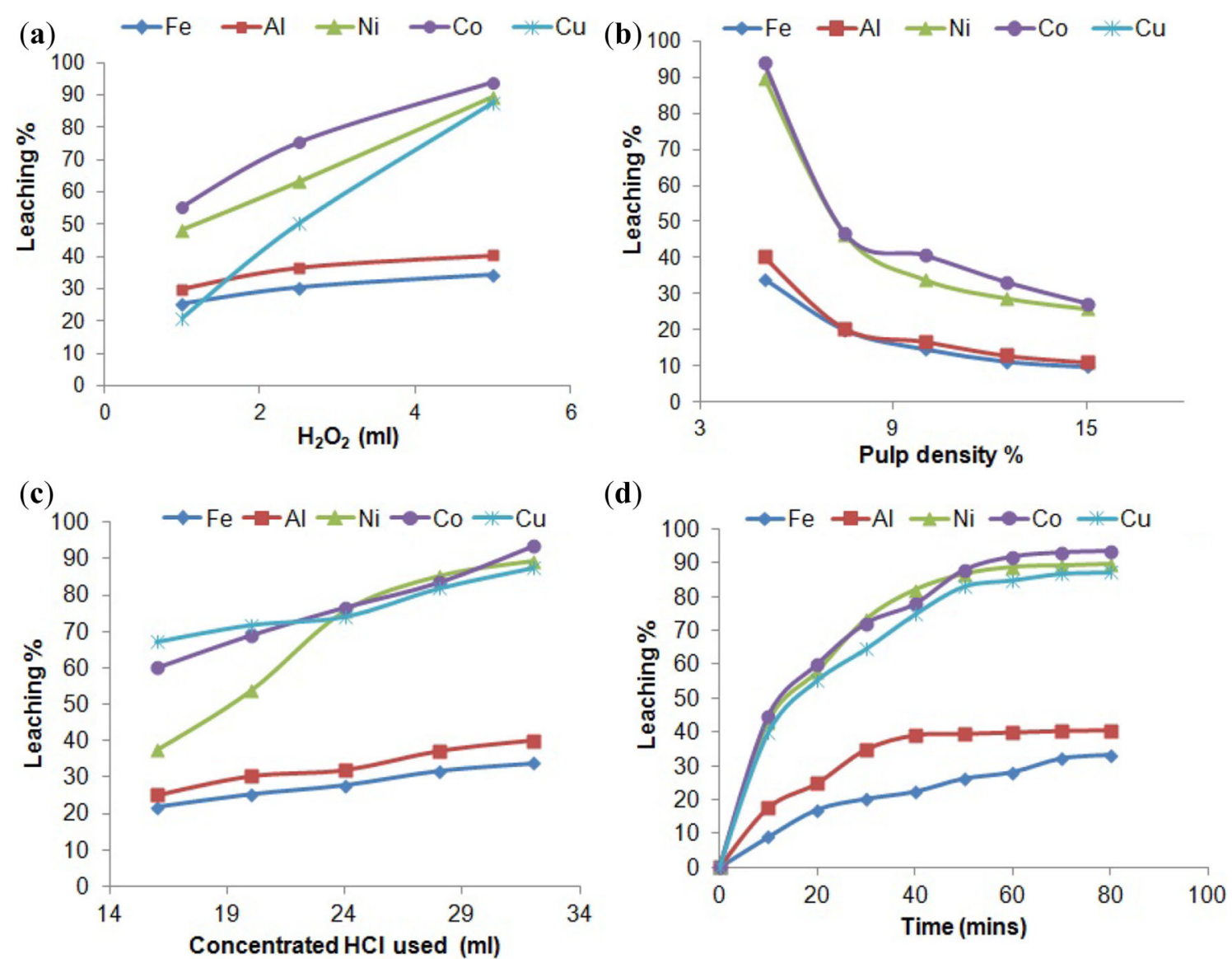

Figure 3. Variation of leaching efficiencies (a) with amount of $\mathrm{H}_{2} \mathrm{O}_{2}$, (b) with pulp density, (c) with concentrated $\mathrm{HCl}$ acid and (d) with time.

gases [31]. At higher temperature, the excess $\mathrm{HCl}$ is converted to molecular chlorine $\left(\mathrm{Cl}_{2}\right)$.

$$
\begin{gathered}
4 \mathrm{HCl}+\mathrm{O}_{2} \leftrightarrow 2 \mathrm{Cl}_{2}+2 \mathrm{H}_{2} \mathrm{O} . \\
\mathrm{Cl}_{2}+\mathrm{H}_{2} \mathrm{O}+\mathrm{SO}_{2} \leftrightarrow \mathrm{SO}_{3}+2 \mathrm{HCl} .
\end{gathered}
$$

The oxidation of $\mathrm{HCl}$ to molecular chlorine $\left(\mathrm{Cl}_{2}\right)$ in excess oxygen served as catalyzed reaction and is also called as Deacon Reaction which is represented by Eq. (1). Further studies related for these flue gases are under process.

\subsection{Leaching studies}

The metallic portion was ground to different particle sizes such as $<150 \mu \mathrm{m}, \quad 150-200 \mu \mathrm{m}, \quad 250-500 \mu \mathrm{m}$ and $>500 \mu \mathrm{m}$. The leaching studies were carried out at room temperature. Very poor leaching of copper was observed with hydrochloric acid ( $\mathrm{HCl})$. This is because $\mathrm{Cu}$ is only leached in the presence of oxidative environment. Since $\mathrm{HCl}$ is a non-oxidising acid, it is not able to solubilize $\mathrm{Cu}$ without an external oxidising agent. Hence for further experiments, hydrogen peroxide $\left(\mathrm{H}_{2} \mathrm{O}_{2}\right)$ was used. The $\mathrm{H}^{+}$ and $\mathrm{Cl}^{-}$ions both accelerate the leaching of copper from e- waste and have the synergetic effect on copper dissolution. As shown in Eq. (3), the metallic copper was oxidized by $\mathrm{H}_{2} \mathrm{O}_{2}$ to cupric ions in acidic solutions [32].

$$
\begin{aligned}
\mathrm{Cu}+\mathrm{H}_{2} \mathrm{O}_{2}+2 \mathrm{H}^{+} & \rightarrow \mathrm{Cu}^{2+}+2 \mathrm{H}_{2} \mathrm{O} \\
\mathrm{Cu}^{2+}+\mathrm{Cu} & \rightarrow 2 \mathrm{Cu}^{+} \\
\mathrm{Cu}^{+}+\mathrm{nCl}^{-} & \rightarrow \mathrm{CuCl}_{\mathrm{n}}^{(\mathrm{n}-1)-} \\
2 \mathrm{CuCl}_{\mathrm{n}}^{(\mathrm{n}-1)-}+2 \mathrm{H}^{+}+\mathrm{H}_{2} \mathrm{O}_{2} & \rightarrow 2 \mathrm{Cu}^{2+}+2 \mathrm{H}_{2} \mathrm{O}+2 \mathrm{nCl}^{-}
\end{aligned}
$$

$\mathrm{The} \mathrm{Cu}^{2+}$ concentration in solutions increases with the leaching of metallic copper from e-waste in acidic solutions of $\mathrm{H}_{2} \mathrm{O}_{2}$, and then the other reaction between metallic copper and $\mathrm{Cu}^{2+}$ in chloride media occurs as illustrated in Eq. (4). Thermodynamically, Eq. (4) proceeds from left to right by increasing the concentration of $\mathrm{Cu}^{2+}$ and/or decreasing the concentration of $\mathrm{Cu}^{+}$. As shown in Eq. (5), $\mathrm{Cu}^{+}$is steadily removed by the formation of complex ions $\mathrm{CuCl}_{n}^{(\mathrm{n}-1)-}$ [31] . These complex ions $\mathrm{CuCl}_{\mathrm{n}}^{(\mathrm{n}-1)-}$ are also oxidized as shown in Eq. (6), and subsequently, generated $\mathrm{Cu}^{2+}$ enhanced the leaching of copper to generate $\mathrm{Cu}^{+}$ions through Eq. (4), 


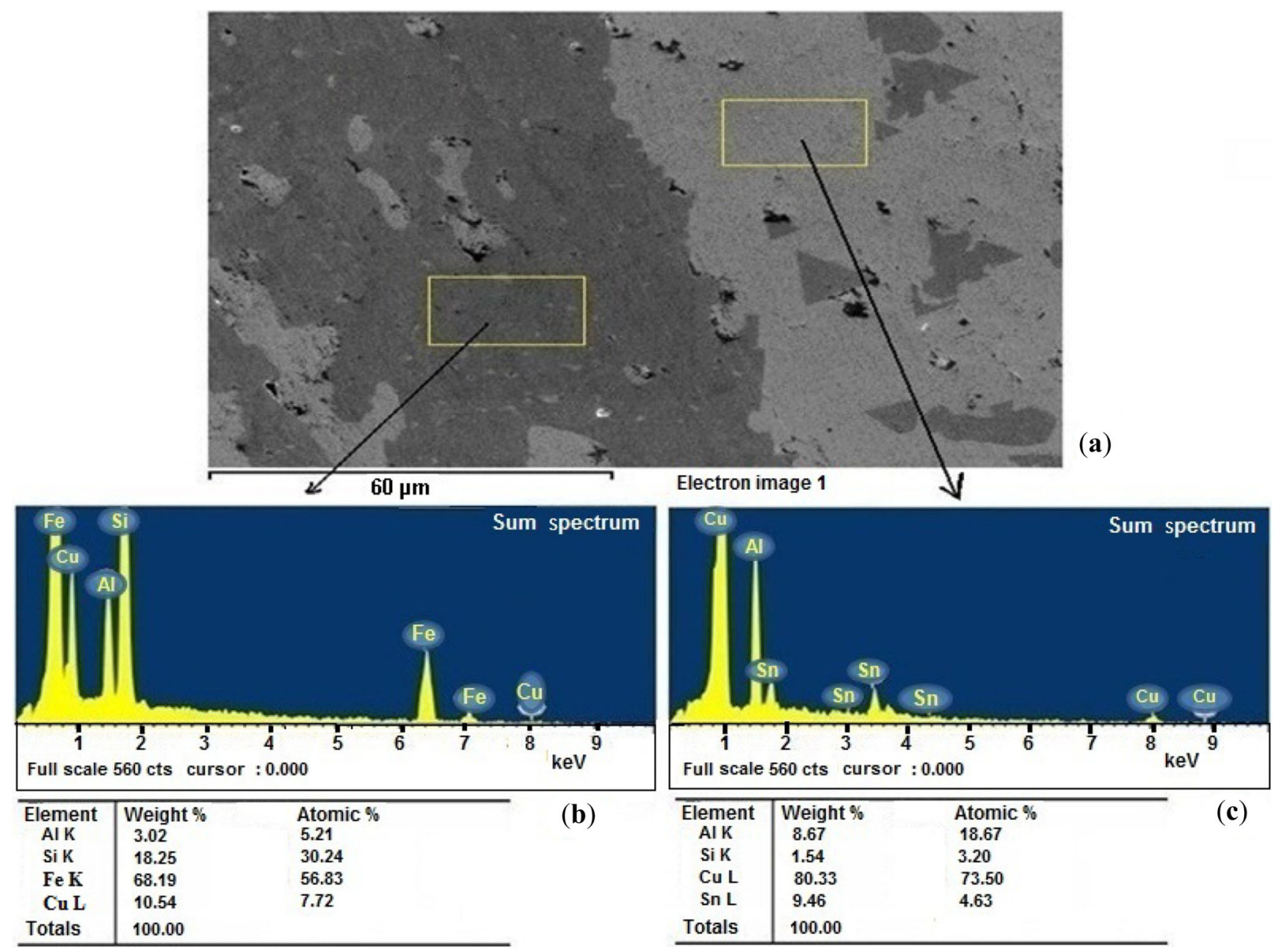

Figure 4. (a) FESEM - EDX image. (b) Metal showing Fe-rich regions. (c) Metal showing Cu-rich regions after cementation process.

which could account for the accelerating effecting of $\mathrm{Cl}^{-}$and $\mathrm{Cu}^{2+}$ on the leaching of metallic copper from e-waste in solutions of $\mathrm{H}_{2} \mathrm{O}_{2}-\mathrm{HCl}$. Consequently, the leaching reaction is accelerated through Eq. (4) by $\mathrm{Cu}^{2+}$ as well as through Eqs. (5) and (6) by $\mathrm{Cl}^{-}$and $\mathrm{H}_{2} \mathrm{O}_{2}$.

Figure 3 shows the graph for the leaching efficiencies of the metal values as a function of different variables. All the experiments were carried out at ambient temperature. Around $90 \%$ of leaching for $\mathrm{Cu}, \mathrm{Ni}$ and $\mathrm{Co}$ was observed in a time span of 1 hour. However $\mathrm{Fe}$ and $\mathrm{Al}$ were observed to have leaching efficiency of around $40 \%$. Figure 3 a shows for the experiment carried out for the variation of leaching efficiencies with amount of hydrogen peroxide $\left(\mathrm{H}_{2} \mathrm{O}_{2}\right)$ whereas figure $3 \mathrm{~b}$ shows for variation of leaching efficiencies with pulp density. The variations of leaching efficiencies with concentrated hydrochloric acid $(\mathrm{HCl})$ and time are also shown in figure $3 \mathrm{c}$ and $\mathrm{d}$, respectively.

Around $90 \%$ of leaching for copper, nickel and cobalt were observed in the time span of eighty minutes. However, $\mathrm{Fe}$ and $\mathrm{Al}$ were observed to have leaching efficiency of around $40 \%$. The reasons have been discussed in the FESEM and XRD section. Leaching resulted in Copper rich liquor $(90 \% \mathrm{Cu})$ which was subjected to cementation. The leached residue was analyzed for gold and silver, which was already studied with XRD, FESEM and TEM studies [32].

The typical composition (in $\mathrm{g} / \mathrm{L}$ ) of the leach liquor contains $\mathrm{Cu}$ : 23.78, Fe: 1.31, Al: 0.63, Co: 0.16, Ni: 0.19. From the leach liquor composition, it was observed that the leach liquor contained around $90 \%$ of copper. For cementation studies, iron powder was used at a stoichiometric ratio of 1:1. The cementation kinetics was very fast and equilibrium was achieved within 15 minutes with the efficiency of around $90 \%$. In result, copper powder was obtained having $78-83 \%$ of copper.

\subsection{FESEM - EDX and elemental image mapping studies}

The results obtained with FESEM - EDX and image mapping studies are shown in figures 4 and 5, respectively for analysis of micro structural characterizations/morphologies of the metallic portion obtained after microwave treatment . Here figure 4a shows the SEM image of the metal whereas figure $4 \mathrm{~b}$ and $4 \mathrm{c}$ show the spectrum and EDX analysis of the $\mathrm{Fe}$-rich and $\mathrm{Cu}$-rich portions, respectively. 

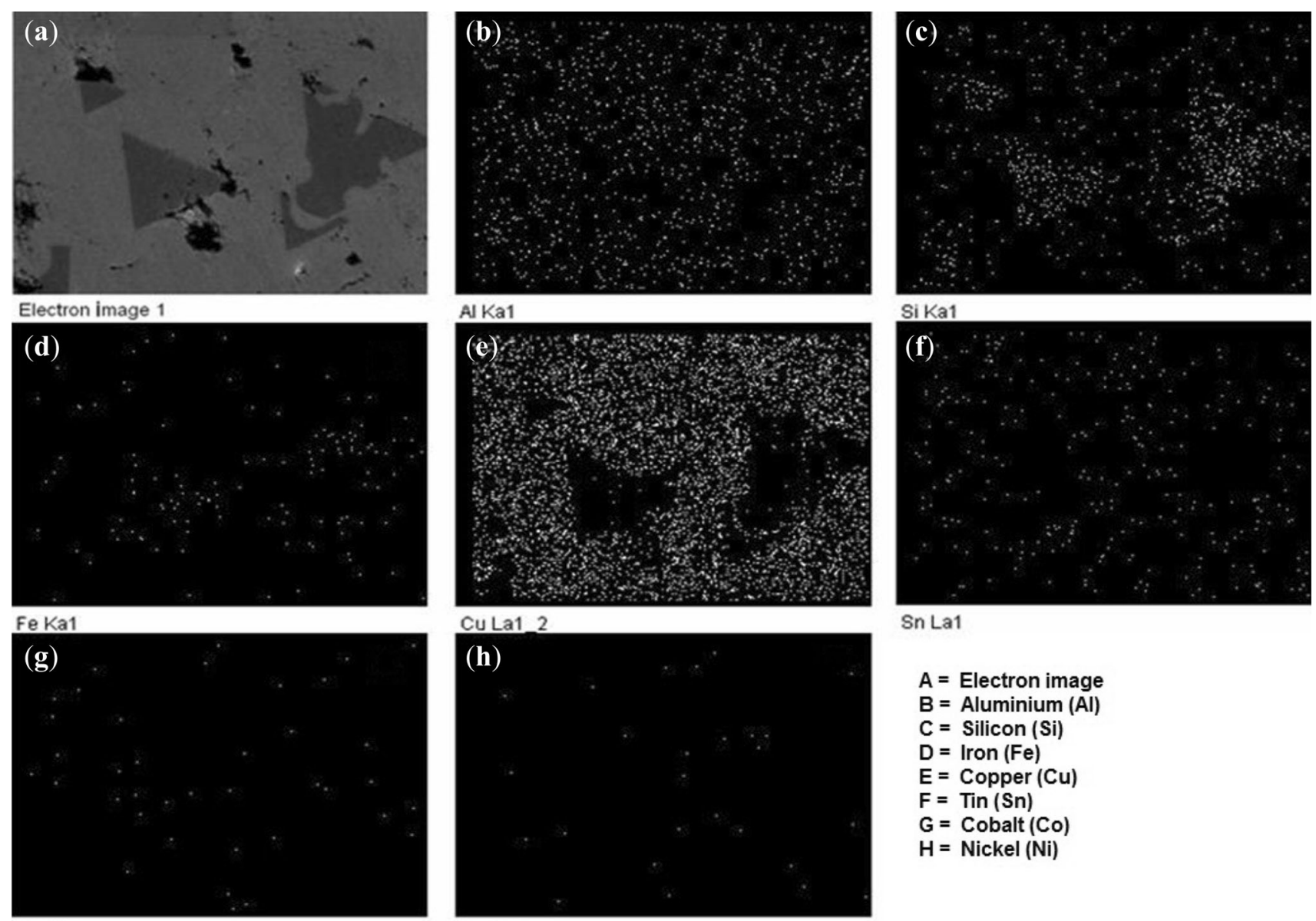

Sn La1

$$
\begin{aligned}
& A=\text { Electron image } \\
& B=\text { Aluminium }(\mathrm{Al}) \\
& \mathrm{C}=\operatorname{Silicon}(\mathrm{Si}) \\
& \mathrm{D}=\operatorname{Iron}(\mathrm{Fe}) \\
& \mathrm{E}=\operatorname{Copper}(\mathrm{Cu}) \\
& \mathrm{F}=\operatorname{Tin}(\mathrm{Sn}) \\
& \mathrm{G}=\operatorname{Cobalt}(\mathrm{Co}) \\
& \mathrm{H}=\operatorname{Nickel}(\mathrm{Ni})
\end{aligned}
$$

Figure 5. Image elemental mapping with FESEM - EDX analysis.
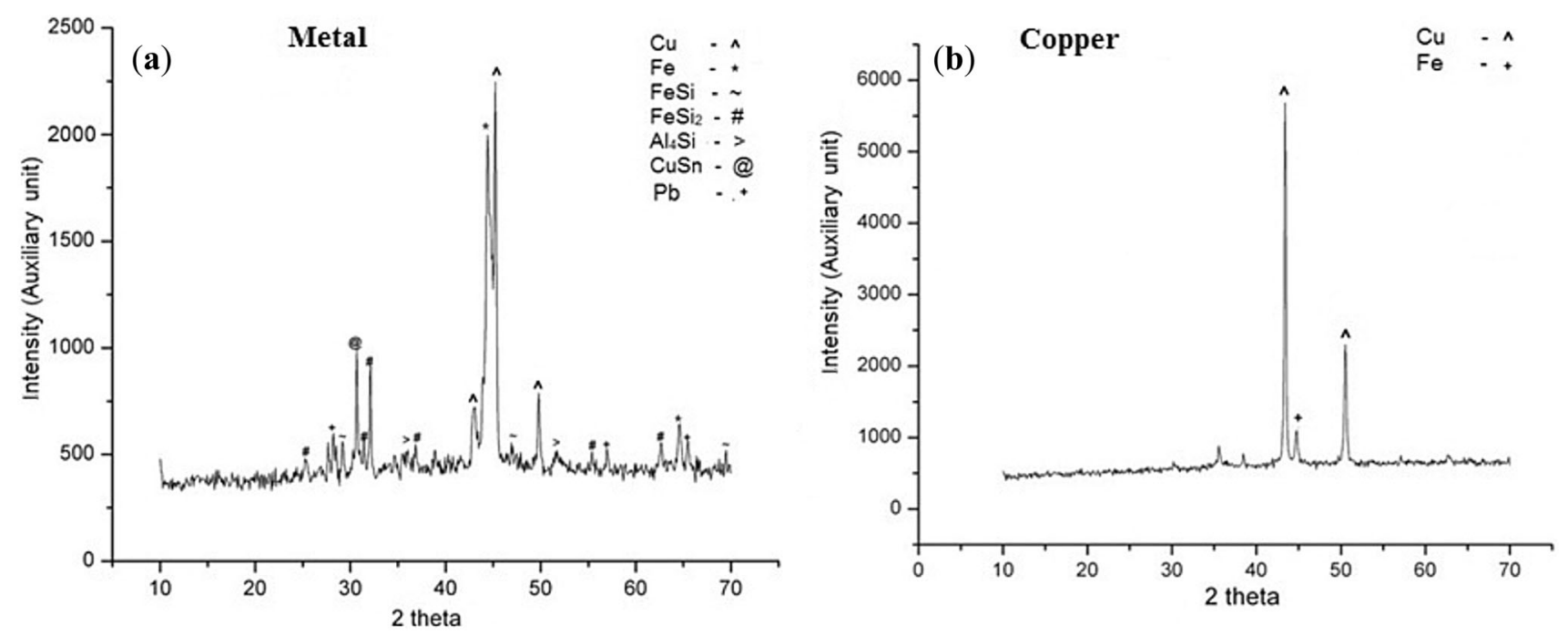

Figure 6. XRD of the (a) metal. (b) Copper sponge. 
Figure 5 shows the X-ray elemental image mapping of the elements present in the $\mathrm{Cu}$ rich region of the metal. It shows the distribution of individual elements like $\mathrm{Cu}, \mathrm{Fe}$, $\mathrm{Al}, \mathrm{Si}, \mathrm{Sn}, \mathrm{Co}$ and $\mathrm{Ni}$. It is quite evident that $\mathrm{Si}$ rich portion does not have $\mathrm{Cu}$ in it and vice versa. Similarly, $\mathrm{Fe}$ is present in very minimal amount, where $\mathrm{Cu}$ is rich, which is also evident from the EDX analysis of the $\mathrm{Cu}$ and $\mathrm{Fe}$ rich portions. Hence, $\mathrm{Cu}$ has possibly not formed any alloy with $\mathrm{Si}$ or Fe. Distribution of $\mathrm{Al}$ and $\mathrm{Si}$ suggests that they might have formed alloys with each other. Similarly, the elemental maps suggest that $\mathrm{Cu}-\mathrm{Sn}$ and $\mathrm{Fe}-\mathrm{Si}$ alloys might be there. However, the phase diagram between $\mathrm{Cu}-\mathrm{Fe}, \mathrm{Cu}-\mathrm{Al}$, $\mathrm{Al}-\mathrm{Si}, \mathrm{Cu}-\mathrm{Sn}, \mathrm{Fe}-\mathrm{Si}$ indicated that $\mathrm{Cu}-\mathrm{Fe}, \mathrm{Cu}-\mathrm{Al}$ formed eutectic mixture and therefore, on cooling it would form a physical mixture. Further, from the phase diagram studies, it can be concluded that $\mathrm{Al}-\mathrm{Si}, \mathrm{Fe}-\mathrm{Si}$ and $\mathrm{Cu}-\mathrm{Sn}$ would form alloy on cooling the fused mass.

\subsection{XRD studies}

X-ray Powder Diffraction (XRD) study was performed by X-ray powder diffractometer X-Pert from Philips PANalytical [30] contains Mo-K $\alpha$ radiation $(\lambda=0.709 \AA)$. This Mo$\mathrm{K} \alpha$ radiation has $6^{\circ}$ to $70^{\circ}$ scanning angle at a scanning rate of $0.03 \% \mathrm{sec}$ was used. This diffractometer was used for phase analysis of minerals and metals and to determine the presence of chemical components. The sample in a powder form was kept into a sample holder for X-ray Diffraction (XRD) analysis and its data were collected on an X-Pert diffractometer at ambient temperature. Figure 6a shows the XRD analysis of the metallic portion. Identified phases are copper $(\mathrm{Cu})$, iron $(\mathrm{Fe})$, aluminium $(\mathrm{Al})$, silicon $(\mathrm{Si})$ in metallic form and aluminium-silicon (Al-Si), copper - tin ( $\mathrm{Cu}-\mathrm{Sn})$ and iron - tin ( $\mathrm{Fe}-\mathrm{Si})$ in alloy form. From the phase studies, it was concluded that all the elements like copper $(\mathrm{Cu})$, iron $(\mathrm{Fe})$, aluminium $(\mathrm{Al})$, silicon $(\mathrm{Si})$, lead $(\mathrm{Sn})$, cobalt $(\mathrm{Co})$ and nickel (Ni) were either in metallic form or in alloy form. In none of the cases, the metals were in the oxide form. The non-formation of the oxides during microwave heating may be due to the presence of inert gas (here Argon gas) and emission of carbon monoxide (CO) due to the burning of organic materials which was the part and parcel of the e-waste. Since, most of the copper $(\mathrm{Cu})$ did not form any alloy with other elements, it could be leached easily, while $\mathrm{Fe}$ and $\mathrm{Al}$ formed alloys with each other and also with $\mathrm{Si}$, they showed poor leaching efficiencies. Figure $6 \mathrm{~b}$ shows the X-ray powder diffraction (XRD) of the Cu sponge obtained from the leach liquor which showed copper $(\mathrm{Cu})$ as the major peak. Figure 7 shows the $\mathrm{X}$-ray powder diffraction (XRD) of the leached residue.

\subsection{Material balance}

Tables 1, 2, 3, 4 and 5 show the material balances of entire process in a batch scale investigations. Table 1 shows the

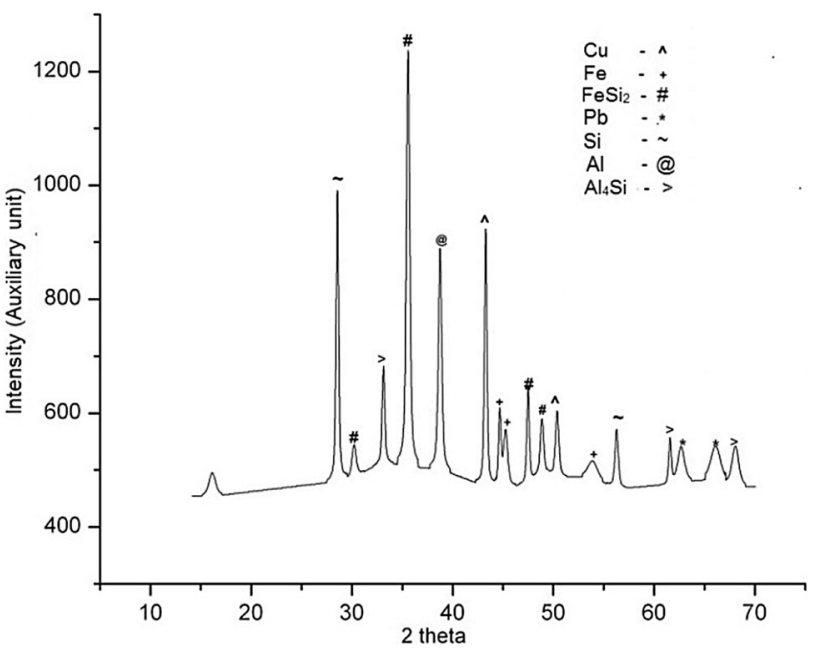

Figure 7. XRD of the leached residue.

Table 1. Sample (5 g) after microwave heating.

\begin{tabular}{lcc}
\hline Element & Metal composition $(\%)$ & Weight $(\mathrm{g})$ \\
\hline $\mathrm{Cu}$ & 54.30 & 2.715 \\
$\mathrm{Fe}$ & 12.99 & 0.650 \\
$\mathrm{Al}$ & 9.79 & 0.490 \\
$\mathrm{Ni}$ & 1.13 & 0.057 \\
$\mathrm{Co}$ & 0.50 & 0.025 \\
$\mathrm{Si}$ & 7.00 & 0.350 \\
\hline
\end{tabular}

Table 2. Sample after leach liquor-cementation process.

\begin{tabular}{lcc}
\hline Element & Weight after leach liquor $(\mathrm{g})$ & Composition $(\%)$ \\
\hline $\mathrm{Cu}$ & 2.4910 & 85.4 \\
$\mathrm{Fe}$ & 0.2210 & 6.4 \\
$\mathrm{Al}$ & 0.1220 & 5.8 \\
$\mathrm{Ni}$ & 0.0550 & 1.5 \\
$\mathrm{Co}$ & 0.0235 & 0.8 \\
\hline
\end{tabular}

Table 3. Leach residue sample process.

\begin{tabular}{lcc}
\hline Element & Weight in leach liquor $(\mathrm{g})$ & Composition $(\%)$ \\
\hline $\mathrm{Cu}$ & 0.19 & 14.62 \\
$\mathrm{Fe}$ & 0.41 & 27.69 \\
$\mathrm{Al}$ & 0.36 & 23.9 \\
\hline
\end{tabular}

metal sample in terms of composition percent $(\%)$ and weight $(\mathrm{g})$ obtained after microwave heating of crushed e-waste sample. The entire mass balance study was performed for $5 \mathrm{~g}$ of each sample. It was observed that heated e-waste sample contains $54.3 \%$ copper $(\mathrm{Cu}), 12.99 \%$ of iron $(\mathrm{Fe}), 9.79 \%$ aluminium $(\mathrm{Al}), 0.28 \%$ lead $(\mathrm{Pb}), 1.13 \%$ nickel $(\mathrm{Ni}), 0.5 \%$ cobalt $(\mathrm{Co})$ and $7 \%$ silicon $(\mathrm{Si})$. The sample after leaching process i.e., microwave heated sample was treated with $\mathrm{HCl}$ acid in the presence of oxidizing agent hydrogen peroxide $\left(\mathrm{H}_{2} \mathrm{O}_{2}\right)$ producing around $90 \%$ of 
Table 4. Weight after leach liquor and leach residue along with mass balance process.

\begin{tabular}{lcccc}
\hline Element & $\begin{array}{c}\text { Metal } \\
(\mathrm{g})\end{array}$ & $\begin{array}{c}\text { Leach } \\
\text { liquor }(\mathrm{g})\end{array}$ & $\begin{array}{c}\text { Residue } \\
(\mathrm{g})\end{array}$ & $\begin{array}{c}\text { Mass balance after } \\
\text { leach liquor }(\%)\end{array}$ \\
\hline $\mathrm{Cu}$ & 2.715 & 2.4910 & 0.19 & 98.65 \\
$\mathrm{Fe}$ & 0.650 & 0.2210 & 0.41 & 92.10 \\
$\mathrm{Al}$ & 0.490 & 0.1220 & 0.36 & 91.50 \\
$\mathrm{Ni}$ & 0.057 & 0.0550 & 0 & 96.50 \\
$\mathrm{Co}$ & 0.025 & 0.0235 & 0 & 94.00 \\
\hline
\end{tabular}

Table 5. Comparison of present work with Rath et al investigation [12].

\begin{tabular}{lcc}
\hline Element & $\begin{array}{c}\text { Mass balance after leach } \\
\text { liquor (present study) }\end{array}$ & $\begin{array}{c}\text { Rath's et al investigation } \\
\text { with plasma technology [12] }\end{array}$ \\
\hline $\mathrm{Cu}$ & $98.65 \%$ & $91.05 \%$ \\
$\mathrm{Fe}$ & $92.10 \%$ & No information \\
$\mathrm{Al}$ & $91.50 \%$ & No information \\
$\mathrm{Ni}$ & $96.50 \%$ & $94.42 \%$ \\
$\mathrm{Co}$ & $94.00 \%$ & $93.31 \%$ \\
\hline
\end{tabular}

copper rich liquor composition followed with cementation process as shown in table 2 . It is observed that during cementation process, copper ions in leach residue solution are precipitated out in the presence of solid iron. These iron oxidize, and with the transfer of electrons, the copper ions are reduced. This chemical reactions are spontaneous because copper is assumed to be higher on the galvanic series than iron.

$$
\mathrm{Cu}^{2+}(\mathrm{aq})+\mathrm{Fe}(\mathrm{s}) \rightarrow \mathrm{Fe}^{2+}(\mathrm{aq})+\mathrm{Cu}(\mathrm{s})
$$

Table 3 shows the trailing after cementation process i.e., leach residue. It is observed that from the summary table as shown in table 4, the composition of $\mathrm{Cu}$ powder is $98.65 \%$ whereas the composition of iron and aluminium are $92.1 \%$ and $97.8 \%$, respectively.

The present investigations have been compared with the available data from Rath et al [12], where the e-waste has been optimized with response surface methodology using thermal plasma method followed by acid leaching. The composition for $\mathrm{Cu}, \mathrm{Co}$ and $\mathrm{Ni}$ as listed in table 5, were recovered as $91,93.3$ and $94.42 \%$, respectively by using thermal plasma method [12] which are comparable to the present investigation showing $98.65 \% \mathrm{Cu}, 92.1 \% \mathrm{Fe}$, 91.5\% Al, 96.5\% Ni and 94\% Co recovery from e-waste.

\section{Conclusion}

The hazardous e-waste was treated in a microwave sintering to recover the useful metal values. The microwave heating process is found to be generating less waste as compared to conventional treatments and also with lesser time. The following conclusions are drawn in the present investigations on e-waste to recover selected valuable metal components like copper, nickel, cobalt with microwave heating followed by leaching process.

- In the microwave heat treatment process, at first instance the crushed e-waste was melted to recover the metal values as a metallic mixture at a good efficiency. The flue gas generated was environmentally acceptable unlike the ones emitted by traditional pyrometallurgical routes. However, the studies related to flue gas generated are still in progress.

- All leaching analysis depends on the leaching parameters like acid concentration in stochiometric ratio, reaction time and hydrogen peroxide dosage.

- However, it is seen that copper could only selectively get leached with the addition of oxidizing agent as hydrogen peroxide. The low leaching efficiencies for iron and aluminium are due to the formation of alloy.

- The physico-chemical studies like FESEM, SEM-EDX and XRD studies of the metallic product in the present investigation revealed that copper was in metallic form, whereas, aluminium and iron formed alloys with silicon and others.

- It is observed that leach liquor produced contained around $90 \%$ copper, which was subjected to cementation using iron powder and around $85 \%$ pure copper powder and $\mathrm{Fe}(6.4 \%)$ has been achieved in metal form. The other components (usually in alloy form) recovered with this process are $\mathrm{Al}(5.8 \%)$, Co (0.8\%) and (Ni 1.5\%).

- Thus, recovery of the base metals from e-waste sample is possible with the judicious combination of leaching and microwave treatment.

\section{Acknowledgement}

The authors are grateful to the Director and Scientists/ Researchers of CSIR-Institute of Minerals and Materials Technology, Bhubaneswar for extending the facilities to carry out the work and guiding us with their Mineral and Material processing experience. This research work did not receive any specific grant from funding agencies in the public, commercial, or not-for-profit sectors.

\section{References}

[1] Chauhan G, Prashant R J, Pant K K and Nigam K D P 2018 Novel technologies and conventional processes for recovery of metals from waste electrical and electronic equipment: challenges and opportunities-a review. J. Environ. Chem. Eng. 6: 1288-1304

[2] Isildar A, Eldon R R, Eric D V H and Piet N L L 2018 Electronic waste as a secondary source of critical metals: 
management and recovery technologies. Resour. Conserv. Recycl. 135: 296-312

[3] Xue M, Kendall A, Xu Z and Schoenung J M 2015 Waste management of printed wiring boards: a life cycle assessment of the metals recycling chain from liberation through refining. Environ. Sci. Technol. 49: 940-947

[4] Khanna R, Cayumil R, Mukherjee P S and Sahajwalla V 2014 A novel recycling approach for transforming waste printed circuit boards into a material resource. Procedia Environ. Sci. 21: 42-54

[5] Martha C, Araceli G, Juan A C and Consuelo M C 2009 Characterization of fly ash from a hazardous waste incinerator in Medellin, Colombia. J. Hazard. Mater. 168: 1223-1232

[6] Saidan M, Brown B and Valix M 2012 Leaching of electronic waste using biometabolised acids. Chin. J. Chem. Eng. 20: $530-534$

[7] Das A, Vidyadhar A and Mehrotra S P 2009 A novel flowsheet for the recovery of metal values from waste printed circuit boards. Resour. Conserv. Recycl. 53: 464-469

[8] Cui J and Zhang L 2008 Metallurgical recovery of metals from electronic waste: a review. J. Hazard. Mater. 158: 228-256

[9] Swarnil D and Jana T 2014 E-waste recycling technologypatents filed in India-an analysis. J. Intellect. Prop. Rights 19: $315-324$

[10] Schlummer M, Gruber L, Maurer A, Wolz G and Van E R 2007 Characterisation of polymer fractions from waste electrical and electronic equipment and implications for waste management. Chemosphere 67: 1866-1867

[11] Chitsan L, Yi-Ming K and Kuo-Lin H 2012 Metal behavior during vitrification of municipal solid waste incinerator fly ash. Aerosol Air Qual. Res. 12: 1379-1385

[12] Rath S S, Nayak P, Mukherjee P S, Chaudhury G R and Mishra B K 2012 Treatment of electronic waste to recover metal values using thermal plasma coupled with acid leaching - a response surface modeling approach. Waste Manag. 32: 575-583

[13] Schlummer M, Maurer A, Leitner T and Spruzina W 2006 Report: recycling of flame-retarded plastics from waste electric and electronic equipment. Waste Manag. Res. 24: $573-583$

[14] Xue M and Xu Z 2016 Application of life cycle assessment on electronic waste management: a review. Environ. Manag. 59: 693-707

[15] Abdul K, Rhamdhani M A, Brooks G and Syed M 2014 Metal extraction process for electronic waste and existing industrial routes: a review and Australian perspective. $R e$ sources 3: 152-179

[16] Congren Y, Li J, Tan Q and Dong Q 2017 Green process of metal recycling: co-processing waste printed circuit boards and spent tin stripping solution. Am. Chem. Soc. 5: 3524-3534

[17] Liu X, Tan Q, Li Y, Xu Z and Chen M 2017 Copper recovery from waste printed circuit boards concentrated metal scraps by electrolysis. Environ. Sci. Eng. 11: 1-5
[18] Valix M 2017 Production, isolation and purification of industrial products. In: Current Developments in Biotechnology and Bioengineering, pp. 407-409

[19] Enrique E R, Maria A M, Claudio A O N, Denise C R E, Renato O, Guilherme O and Marcio R C 2017 Bioleaching of electronic waste using bacteria isolated from the marine sponge Hymeniacidon heliophila (Porifera). J. Hazard. Mater. 329: 120-130

[20] Hong Y and Valix M 2014 Bioleaching of electronic waste using acidophilic sulfur oxidising bacteria. J. Clean. Prod. 65: $465-472$

[21] Weijin W, Xiaocui L, Zhu M, Xu Z and Wensong T 2018 Bioleaching of copper from waste printed circuit boards by bacteria-free cultural supernatant of iron-sulfur-oxidizing bacteria. Bioresour. Bioprocess. 5: 1-13

[22] En M, Zhang C, Jianfeng B and Wang J 2016 A green method for recycling materials from liquid crystal display panel. In: International IEEE Conference, Berlin, Electronics Goes Green, pp 1-8

[23] Wicks G G, Clark D E, Schulz R L and Folz D C 1995 Microwave Technology for Waste Management Applications: Treatment of Discarded Electronic Circuitry (U). U.S. Department of Energy (DOE). Contract No. DE-ACO996SR1 8500

[24] Kingman S W, Appleton T J, Colder R I, Lowndes I S, and Read A G 2005 Microwave technology for energy-efficient processing of waste. Appl. Energy 81: 85-113

[25] Srikant S S, Mukherjee P S and Rao R B 2013 Prospects of microwave energy in material and mineral processing. Turk. J. Eng. Sci. Technol. 2: 23-31

[26] Srikant S S, Mukherjee P S and Rao R B 2013 Microwave energy for waste management. Min. Proc. Technol. 3: 948-953

[27] Pickles C A 2009 Microwaves in extractive metallurgy: part $1-\mathrm{a}$ review of fundamental. Miner. Eng. 22: $1102-1111$

[28] Srikant S S, Mukherjee P S and Rao R B 2014 Morphological characterization of Titania slag obtained from Red Sediment Placer Ilmenite using microwave energy. J. Inst. Eng. Ser. D 96: 43-49

[29] Jing S, Wang W, Liu Z and Ma C 2011 Recycling of waste printed circuit boards by microwave-induced heating and featured mechanical processing. Industrial and Engineering Research 50: 11763-11769

[30] Jing S, Wang W, Liu Z and Ma C 2011 Study of the transference rules for bromine in waste printed circuit boards during microwave-induced pyrolysis. J. Air Waste Manag. Assoc. 61: 535-542

[31] Liu K, Pan W P and Riley J T 2000 A study of chlorine behavior in a simulated fluidized bed combustion system. Fuel 79: 1115-1124

[32] Wang Z, Guo S, Ye C 2016 Leaching of copper from metal powders mechanically separated from waste printed circuit boards in chloride media using hydrogen peroxide as oxidant. Procedia Environ. Sci. 31: 917-924 